\title{
Storage of Water in California by Riparians and Appropriators
}

\author{
Economic Necessity for Storage of Water
}

$\mathrm{F}$

ROM the very beginning California has depended upon its water supply to support its predominant industries. It was water which made possible the mining operations of the pioneers. It was water that gave the opportumity to develop our agricultural potentialities by artificial irrigation. And it is upon water-power that depends the fulfillment of any hope for state-wide manufacturing industry, for we have no coal deposits of practical significance.

The normal surface supply of our streams was the original supply of water. But this was taken up long ago. ${ }^{1}$ Various underground or artesian areas constituted the next source of supply. But this too has been found insufficient to meet increasing demands. Apparently all that is now left for new uses on any large scale is the winter supply of floods that now for the most part sweep on to the ocean without utility to any one.

As stated by Mr. Chief Justice Shaw:

"The demand for additional water ... continues without abatement and with constantly increasing urgency, because of the continuing influx of population and the large area of land capable of vastly increased production, when water is applied by artificial means.

"The next process in the development of the use of water [is] the storing of water in elevated reservoirs in the mountains." 2

\section{IMPORTANCE OF PROBLEM}

That the power and irrigation interests are fully alive to the necessity and importance of storing water for increased needs is seen from the very numerous examples of the construction of reservoirs on all our important streams by power companies and irrigation districts. The amount of money involved is so stupendous as to be almost beyond comprehension.

Notwithstanding all this expenditure of money no one knows

1 Address by Chief Justice Lucien Shaw on The Development of the Law of Water in the West, reprinted in $189 \mathrm{Cal}$. 779, 793; 10 California Law Review, 443.

2189 Cal. 779, 797. 
upon what principle the right to maintain the reservoirs will be sustained. The Supreme Court has not yet passed upon the problem and such reservoirs as have been built have apparently been constructed upon the principle that prescription will cut off the rights of those who do not object and that those who do object can be bought off.

However in a recent case ${ }^{3}$ one of our largest power companies refused to meet the demands of an objecting riparian owner below, but insisted that as it was also a riparian owner it was entitled to construct reservoirs to store waters particularly at the times and at the stages when it would not interfere with the reasonable needs of riparian owners below.

This power company also asserted rights as an appropriator but its argument was confined mainly to a discussion of riparian rights. However, numerous amici curiae filed briefs in support of the power company, but, peculiarly, denied its right to store as a riparian, urging that its right to store should rest upon the principles of appropriation. The widespread interest occasioned by this case is seen from the fact that briefs as amici curiae were filed on behalf of the United States, the United States Bureau of Reclamation, the State of California, the State Water Commission, the Irrigation District Association of California and over 30 irrigation districts. In addition, separate briefs on behalf of various power company interests were filed by former Chief Justice Shaw and former Justice Olney.

In this particular case the Southern California Edison Company had constructed storage reservoirs and other works on the upper reaches of the San Joaquin River at an estimated cost in excess of $\$ 177,000,000,00$. The reservoirs were to hold water not only for the generation of power but for the benefit of irrigating certain 1iparian lands below. The plaintiff, a riparian owner of certain swamp and overflow and other lands, obtained an injunction in the trial court against further work for storage purposes, on the ground that the contemplated storage was a non-riparian use, and relied upon the principle that a lower riparian could restrain any non-riparian interference with the normal flow of the stream.

This case recalls Lux v. Haggin ${ }^{4}$ for the eminence of the counsel engaged and in the importance of the questions involved. It is particularly important in that the numerous amici curiae were seeking

${ }^{3}$ Herminghaus et al. v. Southern Cal. Edison Company, Supreme Court S. F. No. 11,630 (now pending under submission).

4 (1886) 69 Cal. 255, 4 Pac. 919, 10 Pac. 674. 
directly or indirectly to overturn or curtail the riparian doctrine as enunciated in Lux v. Haggin, or at least to define or modify the riparian doctrine in such a way as to permit non-riparian users to take water declared to be in excess of riparian needs.

\section{Grounds for Sustaining Right to Store}

Aside from such rights as are obtained by contract, condemnation or prescription, the principal methods of obtaiming rights to the use of water in this state are two, namely: by the ownership of lands adjoining a watercourse, which gives rise to what are referred to as riparian rights, or by simply taking possession of the water and applying it to beneficial use under such formalities as may be required by code or statute, which gives rise to what are termed appropriative rights. Under the theory of riparian rights, the right to the use of the waters of a stream belongs to the adjoining owners thereof in a sort of common ownership, each owner having the right to a reasonable share of the waters for proper uses. ${ }^{\circ}$ It has been heretofore generally understood in this state that the rights of riparian owners are paramount to the rights of all other persons, even as against the state. ${ }^{6}$ The doctrine of appropriation is applicable only as among non-riparians. Where a riparian owner is involved on one side and an appropriator on the other, as a general rule, the riparian owner

${ }^{5}$ Miller \& Lux v. Enterprise, etc. Co. (1915) 169 Cal. 415, 440, 147 Pac. 567; Palmer v. Railroad Commission (1914) 167 Cal. 167, 173-4, 138 Pac. 997; Anaheim, etc. Co. v. Fuller (1907) 150 Cal. 327, 335, 88 Pac. 978; Lux v. Haggin (1886) 69 Cal. 255, 390, 4 Pac. 919, 10 Pac. 674; 1 Wiel, Water Rights (3d ed.) p. 792, et seq.

${ }^{6}$ Antioch v. Williams Irr. Dist. (1922) 188 Cal. 451, 463, 205 Pac. 688, referring to appropriators as trespassers against the riparian owners.

San Bernardino v. Riverside (1921) 186 Cal. 7, 13, 198 Pac. 784, stating that "The original rights to the waters of the streams in this state are those which by the common law were vested in the owners of the land abutting upon the streams, under the doctrine of riparian rights, as it is commonly called. Such rights are attached to the land as parcel thereof, and, of course are private property. . . It follows in consequence of this fact that all other present existing rights in the waters of streams have been acquired by contract, or by condemnation. Appropriation under the Civil Code is but another form of prescription, and the original rights of the abutting land owners are not divested thereby until the period of prescription has run in favor of the appropriator."

Palmer v. Railroad Commission (1914) 167 Cal. 163, 167-8, 138 Pac. 997, declaring the usufructuary right of the riparian proprietors is a private vested right and that the doctrine that the waters of non-navigable streams in this state constitute public waters or belong to the state "has no support in the statutes of the state or in any decision of this court". 
can restrain any use whatever by the non-riparian or appropriator, ${ }^{7}$ except as his right has been lost by prescription, contract, condemnation and in certain instances of prior settlement on public lands. However, as will be seen later herein, there are some cases containing language inconsistent with the supposed paramount right of the riparian owner, and a statute purporting to open up to appropriators water declared not needed by riparians, so that the amici curiae in the Herminghaus case ${ }^{8}$ argue that the extent of supposed paramount right of the riparian is at least an open question.

As already seen, the power company in the Herminghaus case relies mainly upon its right as a riparian owner. If the Supreme Court upholds the right to store, and places the right upon riparian principles, there will be no new law developed. But if it rests the right upon appropriative principles, the decision will mark a new stage in water law, which will either be a new definition of riparian rights so as to limit its scope as against non-riparian appropriators or constitute a modification of the riparian doctrine so as to admit other than adjoining proprietors to the use of the waters of a stream.

\section{Right of Riparian to Store Water}

As a general rule a riparian owner is entitled to make any use of the water as it passes his land consistent with the like right of all riparians on the stream. He may use its power as it passes, and may even consume a reasonable share of it for such purposes as irrigation. ${ }^{\circ}$

How far the riparian may detain the water for storage or otherwise is a matter that cannot be stated in exact terms as this right like the riparian right generally, is a correlative one, which one owner shares with all other riparians.

That some detention may be reasonable has been decided. Thus in Stanford v. Felt where the water was detained in a reservoir, the court said :

7 Pabst v. Finmand (1922) 190 Cal. 124, 132, 211 Pac. 11 ; see 12 California Law Review, 322; Miller \& Lux v. Enterprise, etc. Co. 169 Cal. 415, 433, 147 Yac. 567; Huffner v. Sawday (1908) 153 Cal. 86, 91, 94 Pac. 424; Southern Calif. Investment Co. v. Wilshire (1904) 144 Cal. 68, 73, 77 Pac. 767; 1 Wiel, . Water Rights (3d ed.) pp. 862, 865; 5 California Law Review, 199.

8 Supra, n. 3.

\& Mentone Irr. Co. v. Redlands, etc. Co. (1909) 155 Cal. 323, 327, 100 Pac. 1082, stating that "The riparian owner. . has the right to make any use beneficial to himself . . except that, if his use involves a consumption of the water, he may not use more than his reasonable share as compared with other riparian owners." 
"As the defendant Felt is a riparian proprietor, he has a right to such reasonable detention of the water in the use of it. The reasonableness of the detention is involved in the question of reasonable use. Whether the use is reasonable or not, is always a question of fact.... Whether then, the water is reasonably or unreasonably detained, must be a question of fact."10

And that dams may be used in order to facilitate the diversion of water in ditches, mill ponds, and the like, has also been determined.11

But how far may water be stored from the winter season to the summer or irrigating season? And may water be stored from wet years to dry years? These are the questions which are stirring great practical interests today. There are no cases in California deciding these questions, though there are cases mentioning the use of reservoirs and the advantages thereof. ${ }^{12}$ In other states there is also a paucity of authority though cases are cited in the footnotes to support $^{13}$ and deny ${ }^{14}$ the right. As there are no cases in California

10 (1886) 71 Cal. 249, 253, 16 Pac. 900. Accord: 40 Cyc. 563, 570.

11 Lindblom v. Round Valley Water Co. (1918) $178 \mathrm{Cal} .450,452,173$ Pac. 994 (reservoir created by damming stream) note that this case points out that reservoiring water is not a beneficial use per se but only a means to such use; Gallatin v. Corning Irr. Co. (1912) 163 Cal. 405, 410, 126 Pac. 864 (dam and gate to hold flood waters only); San Joaquin, etc. Co. v. Fresno, etc. Co. (1915) 169 Cal. 174, 146 Pac. 426 (dam diverting flood waters used to hold water to float logs); Turner v. James Canal Co. (1909) $155 \mathrm{Cal}$. 82, 92; 99 Pac. 520; Mentone Irr. Co. v. Redlands Electric, etc. Co. (1909) 155 Cal. 323, $100 \mathrm{Pac}$. 1082 (dam used to turn water into electricity-generating plant); Coleman v. Le Franc (1902) 137 Cal. 214, 216, 69 Pac. 1011 (dam used to divert flood waters at flood times when there was abundance for all riparian owners); Fisher v. Feige (1902) 137 Cal. 39, 42-3, 69 Pac. 618 (stating dams did not affect lower owners); Byers v. Colonial Irr. Co. (1901) 134 Cal. 553, 66 Pac. 732; Rindge v. Crags Land Co (1922) 56 Cal. App. 247, 250, 205' Pac. 36; California Bank v. Hampton (1899) 6 Cal. Unrep. 301, 303-4, 57 Pac. 1073. Dams causing damage to lower owners unreasonably may be enjoined. San Joaquin, etc. Co. v. Fresno, etc. Co., 169 Cal. 174-6; Barneich v. Mercy (1902) 136 Cal. 205, 68 Pac. 589; Ferrea v. Knipe (1865) 28 Cal. 341, 345.

${ }_{12}$ Antioch v. Williams Irr. Dist. (1922) 188 Cal. 451, 464, 205 Pac. 685, Shaw, J., pointing out possibilities of storage reservoirs; Gallatin v. Cornintg Irrigation Co., 163 Cal. 405, 415, pointing out evidence indicated advantage of reservoiring water in flood and winter seasons to carry over to dry years and to supplement average years; Miller v. Bay Cities Water Co. (1910) 157 Cal. 256, 287, 107 Pac. 115. Shaw, J., concurring points out value and desirability of storing waste flood waters in reservoirs; Miller \& Lux v. Madera, etc. Co. (1909) 155 Cal. 59, 71, 99 Pac. 502, mentioning reservoirs; People v. Eilk, etc. Co. (1895) 107 Cal. 221, 226, $40 \mathrm{Pac}$. 531 ; see address of Chief - Justice Shaw in 189 Cal. 779, 780, 797, referring to the use of mountain storage for the double purpose of power and irrigation; 1 Wiel, Water Rights (3d ed.) p. 827.

${ }^{13}$ Federal Cases-Sandusky, etc. Co. v. Dixon, etc. Co. (1915) 221 Fed. 200. Alabama-Tennessee, etc. Co. v. Hamilton (1893) 100 Ala. 252. 14 So. 167, 46 Am. St. Rep. 48. Connecticul-DeWitt v. Bissell (1905) 77 Conn. 5.30, 60 Atl. 113. Georgia-Pool v. Lewis (1870) $41 \mathrm{Ga}$. 162, 5 Am. Rep. 526. Iowa-Gehlen Brothers v. Knorr (1897) 101 Iowa, 700. Maine-Davis v 
specifically answering these questions the matter will have to be decided on principle. That there is here involved a use not known to the common law is no bar to a settlement of these questions within the common law of riparian rights. When the question came up not so long ago as to the right of the riparian to use the power of the flow of the stream for the generation of electricity our Supreme Court had no difficulty in recognizing the right on common law principles. $^{15}$ With regard to these very questions, Mr. Chief Justice Shaw has remarked that he did not believe that

"the law applicable to this process will present much difficulty. The legal aspect of these developments should present no very novel problems." 16

Considering the matter generally, the cases make it clear that the exercise and scope of the riparian right is entirely one of reasonableness under the circumstances. This is largely a question of fact so that as a general rule no use on riparian land can be said to be unreasonable per se..$^{17}$

It is sometimes said to be the common law rule that a lower riparian is entitled to the flow of a stream exactly as it was wont to flow in a state of nature. Of this same contention, the Supreme Court has declared:

"If this supposed rule were strictly enforced against riparian owners, as well as appropriators, the waters of the streams in the

Getchell (1862) 50 Me. 602. Massachusetts-Stratton v. Mt. Hermon Boys School (1913) 216 Mass. 839, 103 N. E. 87; Whitney v. Wheeler, etc. Co. (1890) 151 Mass. 392, 24 N. E. 211; Drake v. Hamilton, etc. Co. (1868) 99 Mass. 574; Gould v. Bostou Duck Co. (1859) 13 Gray (Mass.) 442; Thurber v. Martin (1854) 2 Gray (Mass.) 394, 61 Am. Dec. 468. Michigan-Dumont v. Kellogg (1874) 29 Mich. 420, 18 Am. Rep. 102. New Hampshire-Company v. Gilford (1893) 67 N. H. 514, 35 Atl. 945 . New Jersey-Society, etc. Co. v. Morris Canal Co. (1830) 1 N. J. Eq. 157. New York-Fulton, etc. Co. v. Rockwood (1924) 238 N. Y. 109 ; Pierson v. Speyer (1904) 178 N. Y. 270, 70 N. E. 799, 102 Am. St. Rep. 499; Bullard v. Saratoga, etc. Co. (1879) 77 N. Y. 525; but see Clinton v. Myers (1871) 46 N. Y. 511, 7 Am. Rep. 373. Oregon-Oregon Iron Co. v. Trullenger (1867) 3 Ore. 1. Texas-Stacy v. Delery (1909) 57 Tex. Civ. App. 212, 122 S. W. 300. Virginia-Davis v. Harrisonburg (1914) 116 Va. 864, 83 S. E. 401. Vermont-Canfield v. Andrews (1882) 54 Vt. 1, 41 Am. Rep. 828. Wisconsin-Apfelbacher v. State (1918) 167 Wis. 233, 167 N. W. 244; Coldwell v. Sanderson (1887) 69 Wis. 52,28 N. W. 232

1440 Cyc. 606; Cooley on Torts, p. 694; Clinton v. Meyers (1871) 45 N. Y. 511, 7 Am. Rep. 373; Longmire v. Yakima, etc. Co. (1917) 95 Wash. 302, 163 Pac. 782; Still v. Palouse, etc. Co. (1911) 64 Wash. 606, 117 Pac. 466.

15 Mentone Irr. Co. v. Redlands, etc. Co., 155 Cal. 323, 327.

18189 Cal. $779,797$.

17 Judge Wooley, who decided the Herminghaus case, supra, n. 3, in favor of the lower riparian in the trial court, does believe that storage is nonriparian per se. He says that there is no practical difference between taking the water away from the watershed and withhholding it so that those below can have no benefit from it. 
state could not be used at all, but would flow to the sea, or until they disappeared in the sands and washes, without benefit to anyone, except in the few instances where flood waters might escape naturally and flow upon lands situated similarly to those of the plaintiffs. The rule is evidently not suited to the conditions of a dry climate such as we have in this state.

"It is accordingly well settled here that each riparian owner has a right to a reasonable use of the water on his riparian land for the irrigation thereof, and that the so-called common-law right of each to have the stream flow by his land without diminution, is subject to the common right of all to a reasonable share of the water. [citing cases.] These cases also declare that the determination as to what is the reasonable share of each riparian owner is a question of fact, to be decided according to the circumstances of the case, and that an upper riparian proprietor is entitled to a reasonable use for irrigation, although it may diminish the flow to a lower proprietor, and put him to substantial inconvenience in his use of the stream. ... The question of the right of plaintiffs to have the river maintained at its high flood level for the natural irrigation of their lands, as against an appropriator for public or private use on non-riparian land, is not here presented, and we express no opinion on the subject, mentioning it only to distinguish it." 18

As a question to be decided on the riparian doctrine there is no legal difficulty as to the principles applicable, though there may be in applying the principles to particular facts. It is simply a question of apportionment and partition among co-owners. ${ }^{10}$ It is within the province of the court to tell each riparian owner how much and when he can have the water. Thus it would be proper for the court to tell the power company to take so much water in the winter and the irrigationist so much in the summer. ${ }^{20}$ Where new circumstances

18 Turner v. James Canal Co., 155 Cal. 82, 94-5.

101 Wiel, Water Rights (3d ed.) pp. 820 et seq., collecting the cases; Watson v. Lawson (1913) 166 Cal. 235, 243, 135 Pac. 961 . See also, Pabst v. Finmand, $190 \mathrm{Cal}$. 124, 129; Parker v. Swett (1922) $188 \mathrm{Cal}$. 474, 480, 485, 205 Pac. 1065; Holmes v. Nay (1921) 186 Cal. 231, 235, 199 Pac. 325; Miller \& Lux v. Enterprise, etc. Co., supra, n. 3; Williams v. Costa (1921) 52 Cal. App. 396, 404, 198 Pac. 1017; Peake v. Harris (1920) 48 Cal. App. 363, 381, 192 Pac. 310; Drake v. Tucker (1919) 43 Cal. App. 53, 57, 184 Pac. 502; Felsenthal v. Warring (1919) 40 Cal. App. 119. 132, 180 Pac. 67.

${ }^{20}$ In the Herminghaus case there would be difficulty in applying this rule because there the lower riparian owner depended upon natural overflow to irrigate his land at flood seasons. This method of irrigation has been upheld against non-riparian users on the theory that such persons are strangers to the stream and cannot object to the manner of use by those having paramount rights in the stream. See Miller \& Lux v. Madera, etc. Co. (1909) 155 Cal. 59, 64, 99 Pac. 502. Such a method has not been upheld in any reported case in this state as against a riparian needing the water for more economical uses and is contrary to the rule that waste is not allowable as between riparians. See Holmes v. Nay, $186 \mathrm{Cal}$. 231, 241-2. As to right of lower user to the hydraulic force of entire stream to bring him his share of the water, see Antioch v. Williams Irr. Dist., supra, n. 6. 
should develop, either party could apply to the court for a modification of the decree as may be pertinent.

\section{Right of Appropriators to Store Water}

As between appropriators there does not seem to be any question of the right to store waters. ${ }^{21}$ As among appropriators there is only the question of priority and the first user thereby establishes his right to the extent of previous beneficial use.

The question becomes important and difficult only as between appropriators on the one side and riparians on the other. To one who has studied the course of decisions involving the respective rights of riparians and appropriators in this state, it would seem that this matter was long ago laid to rest in 1886 when Lux v. Haggin ${ }^{22}$ decided that the rights of riparian owners were paramount to those of appropriators or others without prescriptive or contractual rights (or rights as settlers under government patents). That case established the predominant right of riparians over all other users so much so that it has been held that a riparian can enjoin any use by a non-riparian or by a riparian for non-riparian uses, without even showing any present damage or intention to use the water himself.23 This rule has been emphasized by decisions declaring that the waters of the streams belong to the riparians and that no other person had any original interest therein, not even the state. ${ }^{24}$ Hence it has been declared that as against non-riparians, the riparian is not limited in his use of the water by any principle of reasonableness, ${ }^{25}$ or by the fact that he is not making any economic use of the water, ${ }^{26}$ or that the desired non-riparian use is one claimed to be in furtherance of a "public policy" to utilize the waters of the state. ${ }^{27}$

The fact that one particular riparian owner is making no use of the water is under these decisions no reason for letting strangers to

211 Wiel, Water Rights (3d ed.) p. 410.

22 Lux v. Haggin, supra, n. 4.

28 Supra, n. 5.

24 Antioch v. Williams Irr. Dist., 188 Cal. 451, 463; San Bernardino v. Riverside (1921) $186 \mathrm{Cal}$. 7, 13, 198 Pac. 784; Palmer v. Railroad Comm., 167 Cal. $163,167-8$.

${ }_{25}$ Pabst v. Finmand, 190 Cal. 124, 132; Miller \& Lux v. Enterprise. etc. Co., supra, n. 5 ; Miller v. Bay Cities Water Co., supra, n. 12; Miller \& Lux v. Madera, etc. Co., 155 Cal. 59, 64-5; Anaheim, etc. Co. v. Fuller, supra, n. 5 ; Conrad v. Arrowhead Hotel Co. (1894) 103 Cal. 399, 402-3, 37 Pac. 386; ITeilbron v. Fowler Canal Co. (1888) 75 Cal. 426, 432, 17 Pac. 535; Lux v. Haggin, 69 Cal. 255, 396; Felsenthal v. Warring, 40 Cal. App. 119, 132; 1 Wiel, Water Rights (3d ed.) p. 866.

${ }^{26}$ Miller \& Lux v. Enterprise Co., supra, n. 5.

27 Miller \& Lux v. Madera, etc. Co., 155 Cal. $59,65$. 
the stream take any of it. Others of the "common owners" lower down on the stream are entitled to have the water reach them. ${ }^{28}$ Each riparian owner has the right to use the whole or any part of the water on his own riparian land when other riparians are not using the water. ${ }^{28}$

In the face of all these decisions it would require some temerity to say that the appropriator has any original rights against the right of the riparian owners, whether for storage or anything else, so far as the normal flow of a stream is concerned. Yet because of the fact that so many numerous amici curiae in the Herminghaus case ${ }^{80}$ argued that the appropriator has such rights, it becomes important to know upon what basis the appropriative claim is made. As a general matter it may be said that the claim of the appropriation interests rests on two grounds. In the first place they rely upon language in about a half dozen cases involving the use of flood waters in which there are statements to the effect that water in excess of that needed by riparians is open to appropriation. In the second place they rely upon certain provisions of the Water Commission Act which purport to open to appropriation. waters in excess of those reasonably needed by riparians. Each of these grounds will be considered separately.

\section{The Flood Water Cases}

It is the general rule that the riparian owner is entitled to the full normal and natural flow of the stream except as diminished by reasonable riparian uses above or other proper users. ${ }^{31}$ The flow to which the riparian is entitled includes flood waters which are part of the stream, and under the rule that the riparian is entitled to restrain any non-riparian diversion ${ }^{32}$ it has been held that a riparian can stop the diversion of flood waters even though he cannot or does not intend to make any present use of them himself. ${ }^{33}$ It is quite obvious that to permit an injunction against the taking of all

28 Anaheim v. Fuller, 150 Cal. 327, 335; Gould v. Eaton (1891) 117 Cal. 539; 543, 49 Pac. 577.

29 Half Moon Bay, etc. Land Co. v. Cowell (1916) 173 Cal. 543, 549,

160 Pac. 675; San Joaquin, etc. Co. v. Stevinson (1923) 63 Cal. App. 767, 773, 220 Pac. 427; 12 California Law Review, 322.

30 Supra, n. 3.

31 See the cases cited supra, ns, 5, 18 and 19; also in 1 Wiel, Water Rights (3d ed.) p. 807, and Pabst v. Finmand, 190 Cal. 124, 129, 132; San Gabriel v. Los Angeles (1920) $182 \mathrm{Cal}$. 392, 401, 188 Pac. 554; Miller \& Lux v. Enterprise, etc. Co., 169 Cal. 415; Stanford v. Felt (1886) 71 Cal. 249, 250, 16 Pac. 900; Lux v. Haggin, 69 Cal. 255, 390.

82 Supra, n. 7.

33 California, etc. Co. v. Enterprise, etc. Co. (1903) 127 Fed. 741, 743-4; 
floods would require much water to go to waste. To make such flood waters available for use by non-riparians certain cases make a distinction between what is termed an "extraordinary" flood and the normal floods which can be expected to recur regularly. The cases declare that as the extraordinary floods can not be anticipated they are not deemed to be part of the normal flow to which the riparian is entitled but that they constitute a sort of "no man's land" or rather "no man's water" which can be taken or appropriated and kept by the first person who can get control of it. ${ }^{34}$ This distinction between extraordinary and ordinary floods disposes satisfactorily of the apparent conflict between cases granting and denying injunctions to riparians attempting to restrain the non-riparian diversion of floods.

This distinction is one suggested by various cases in the Supreme Court, ${ }^{35}$ and would seem to place the matter at rest, except for the fact that in certain of the opinion $s^{36}$ the court says very broadly that appropriators may take water not needed, usable or benefiting riparians. It is a vast difference to say that the appropriator may take water not needed by the riparian rather than saying that the

Lindblom v. Round, etc. Co. (1918) 178 Cal. 450, 453, 173 Pac. 994; Miller \& Lux v. Enterprise Co., 169 Cal. 447; Miller \& Lux v. Enterprise Co., 169 Cal. 415; Miller v. Bay Cities Water Co., 157 Cal. 256, 272, 281, 283; Miller \& Lux v. Madera, etc. Co., 155 Cal. 49, 62-3, 65, 74-9; Anaheim, etc. Co. v. Fuller, 150 Cal. 327, 334; Heilbron v. Fowler Canal Co. (1888) $75 \mathrm{Cal}$. 426, 432, 17 Pac. 535.

34 Horst Co. v. New Blue Point Mining Co. (1918) 177 Cal. 631, 637-8, 171 Pac. 417; Gallatin v. Corning Irr. Co. (1912) 163 Cal. 405, 126 Pac. 864; San Joaquin, etc. Co. v. Fresno Co., 158 Cal. 626, 629; Coleman v. LeFranc (1902) 137 Cal. 214; 69 Pac. 1011; Fifield v. Spring Valley Water Works (1900) 130 Cal. 552, 554-5, 62 Pac. 1054; Modoc, etc. Co. v. Booth (1894) 102 Cal. 151, 157, 36 Pac. 431; Heilbron v. Land, etc. Co. (1889) 80 Cal. 189, 22 Pac. 62; Edgar v. Stevenson (1886) $70 \mathrm{Cal}$. 286, 11 Pac. 704; Holmes v. Snow, etc. Co. (1918) 36 Cal. App. 394, 172 Pac. 178. The cases are examined and commented upon in 1 Wiel, Water Rights (3d ed.) pp. 872 et seq. Extraordinary fiood waters may be taken by non-riparians or for non-riparian land. $A$ fortiori it would seem that they may be stored in reservoirs. See San Joaquin, etc. Co. v. Fresno, etc. Co., supra, n. 11, and the subsequent opinion in 169 Cal. 174-5, limiting the reservoir right recognized in the former to "times of unusual flood".

35 California, etc. Co. v. Enterprise, etc. Co., 127 Fed. 741, 743; Fresno, etc. Co. v. Peoples, etc. Co. (1917) 174 Cal. 441, 448, 163 Pac. 497; San Joaquin, etc. Co. v. Fresno, etc. Co., 169 Cal. 174-6, holding that one having judgment entitling him to dam streams at times of unusual flood could not maintain the dam so as to interfere with the normal flow; Anaheim v. Fuller, $150 \mathrm{Cal}$. 327, 334, Shaw, J., stating that "unless it can be so reconciled, the [Modoc] case is contrary to all the other decisions of this court above cited and to the settled principles of law, and must be disregarded"; Huffner v. Sawday (1908) 153 Cal. 86, 93, 94 Pac. 424; Vernon Irr. Co. v. Los Angeles (1895) $106 \mathrm{Cal}$. 237, 256-7, 39 Pac. 762, McFarland, J., concurring; Heilbron v. Fowler, $75 \mathrm{Cal} .426,432$.

36 Supra, n. 34. 
appropriator may take water which is not part of the riparian right. For if the appropriator may take water not needed by a particular riparian it is a question in every case as to how much the particular riparian needs and no longer a question as to whether one of the common riparian owners can keep a stranger from touching the property said to belong to one riparian owner in common ownership with all other riparians to the exclusion of mere appropriators who are said to be only trespassers. ${ }^{37}$ Analogously, if several co-tenants owned a tract of riparian land, any one riparian could oust a stranger without having to show how much of the common tract he actually needed for his own use. An answer has been made to this analogy that the riparian owners do not own the corpus of the water of a stream, but only its usufruct. But the Supreme Court has already declared that the fact that the riparian has only a usufruct does not weaken his paramount right as against appropriators. ${ }^{38}$

\section{The State Water Commission Act}

The Water Commission Act declares that all water in excess of that reasonably needed by riparian owners belongs to the state and may be appropriated by persons obtaining its permission and a license upon terms fixed by it. ${ }^{39}$ The Act declares that

"All waters... excepting so far as such waters have been or are being applied to useful and beneficial purposes or ... are or may be reasonably needed .... upon lands riparian thereto, or otherwise appropriated, is and are hereby declared to be public waters of the State of California and subject to appropriation in accordance with the provision of this Act."

If this provision be valid, it is argued by amici curiae in the Herminghaus case that thereby the right of an appropriator to store waters as against a riparian is established. This result may seem rather far-fetched, if deduced as a general consequence of the provision, for the statute does not purport to give such a right. However in the Herminghaus case, the lower riparian was relying upon floods to irrigate his land naturally and it was those floods which the power company wished to store, arguing that it was wasteful for one riparian owner to use such floods as against another riparian when by artificial works the lower owner could use the water at lower stages for any desired irrigation.

${ }^{37}$ Supra, ns. 5 and 6.

38 Palmer v. Railroad Commission, 167 Cal. 163, 167-8; quoted, infra, $n_{0} 41$.

$39 \S 11$ of Water Commission Act. $\S 20$ of that act purports to place certain limitations and restrictions on all appropriations made under the act. 
The provision quoted obviously could not be used to sustain the right of an appropriator to store waters as against a riparian actually making a full, necessary and beneficial use of his share of the water on his own land at normal stages of the river. Hence even if the right to store be sustained against this particular riparian owner on appropriative principles, the case should not be authority for the general proposition that an appropriator may store as against a riparian, though it would be a result of such a decision that riparian owners would no longer have exclusive interests in a stream.

The fundamental objection to the act lies upon its obvious underlying assumption that the state owns the waters of streams in California. The writer is informed that Dr. Pardee, who is primarily responsible for the text in its original form, wrote the act with that principle in mind. The act itself shows that such a principle is intended to be applied, for it declares in so many words that waters in excess of those needed by riparians constitute "public waters".

As to whether or not it would have been better public policy for the courts to have adopted the doctrine of public ownership of the water of this state is not within the scope of this article. Other states have adopted such a doctrine and have deduced either the abolition or curtailment of riparian rights as a consequence therefrom. ${ }^{10}$ Our state Supreme Court has however in emphatic terms rejected the doctrine of public ownership and it will be a difficult task to reconcile a statute based upon the idea of public ownership with decisions announcing private ownership.

Thus in 1914, after the act in question has been passed by the legislature but before its approval by popular referendum, the Supreme Court declared that while it is true that riparian owners have only a usufructuary right to the waters of a stream yet

"This is far from saying that the property in the water is vested in the public, either for general use, or as the property of the state. The doctrine that it is public water, or that it belongs to the state because it is not capable of private ownership, has no support in the statutes of the state or in any decision of this court."11

Upon the petition for rehearing in that case it was urged upon the court that a contrary rule was established by the legislative act of $1911^{42}$ declaring that

101 Wiel, Water Rights (3d ed.) pp. 193 et seq.

11 Palmer v. Railroad Commission, 167 Cal. 163, 168.

42 Cal. Stats. 1911, p. 821. 
"All water or the use of water within the state of California is the property of the people of the state of California."

The court however denied the rehearing stating that such an act could not divest the riparian rights of private owners. ${ }^{43}$ Many other cases affirm the private nature of water rights in this state. ${ }^{41}$

Other states have upheld the validity of legislation similar to the Water Commission Act of 1913. Oregon has done so but its reasoning was based upon the doctrine that in Oregon water rights are a matter of public ownership. ${ }^{45}$ Washington has also recently affirmed such legislation. ${ }^{46}$

There are various grounds urged to sustain the validity of the act. It is declared that the statute does no more than declare the rule said to be laid down in the flood water cases that appropriators may take water in excess of that needed by the riparians; and that if those cases do not decide such a rule they at least leave the nuatter in such doubt that the court is free to resolve the doubt in favor of the statutory declaration.

On constitutional grounds it is said that the statute is no more than a proper exercise of the police power to prevent the waste of our natural resources. Many cases ${ }^{47}$ are cited to show that a man

43 Palmer v. Railroad Commission, 167 Cal. 163, 175-6.

44 Antioch v. Williams Irr. Dist., 188 Cal. 451, 456; San Bernardino v. Riverside, 186 Cal. 7, 13, 25, 29-30; Miller \& Lux v. Enterprise Canal Co., 169 Cal. 415, 441, referring to the confusion which would follow if riparian rights were impaired; Thayer v. California, etc. Co. (1912) 164 Cal. 117, 125, 128 Pac. 21; Miller \& Lux v. Madera, etc. Co., 155 Cal. 59, 64-5, stating that the economic advantage of reservoiring waters for future use could not justify any impairment of riparian rights; Lux v. Haggin, $69 \mathrm{Cal} .255,264$, 307, 390; 10 California Law Review, 111. Compare Allen v. Railroad Commission (1918) $179 \mathrm{Cal}$. 68, 88, 175 Pac. 466, stating that "the constitution of this state and the legislature in pursuance of it has undertaken to put out of existence any and all private rights in the matter of the rental or sale of water. So far as our constitution and laws are concerned the state has done this thing. There stands between it and its enforcement ... the constitution of the United States."

45 Re Hood River (1924) - Ore. -, 227 Pac. 1065.

46 Proctor v. Sim (1925) - Wash. -236 Pac. 114; State v. American Fruit Growers (1925) - Wash. 一, 237 Pac. 498; Brown v. Chase (1923) 125 Wash. 542, 217 Pac. 23.

${ }_{47}$ Antioch v. Williams Irr. Dist., 188 Cal. 451, 468, where the court points out: "Rice, so it is said, requires nine times as much water as ordinary crops. It may be that under these circumstances rice culture in this state should not be encouraged, or that in the exercise of the police power, the use of the waters of the state in that business might be lawfully forbidden. But that is a legislative question." Walls v. Midland Carbon Co. (1920) 254 U.S. 300, 65 L. Ed. 276, 41 Sup. Ct. Rep. 118 (natural gas); Ohio Oil Co. v. Indiana (1899) 177 U. S. 190, 44 L. Ed. 729, 20 Sup. Ct. Rep. 585 (natural gas); Ex parte Elam (1907) 6 Cal. App. 233, 91 Pac. 811 (subterranean waters): Townsend v. State (1897) 147 Ind. 624,47 N. E. 19 (natural gas); Commonwealth v. Trent (1903) $117 \mathrm{Ky} .34,77$ S. W. 390 (natural gas); Opinion 
may be prevented from wasting natural resources even though he has a private title thereto. Such cases would be more analogous if the statute under discussion merely forbade riparians from wasting water. But the statute goes further and purports to give to nonriparians water declared to be in excess of particular needs. It is one thing to say that one co-owner may not waste water as against other co-owners or as against the state, but another thing to give to a stranger water not needed at the particular time by a particular co-owner without regard to the fact that other co-owners on the stream may wish to make use of the supposed excess.

The simplest explanation of the act is that it represents an invitation extended to the Supreine Court asking it to overrule Lux v. Haggin $^{48}$ and all the cases following it in applying the riparian doctrine. On the one hand it is said that the riparian right is a vested property right which may not be confiscated or taken without compensation ${ }^{49}$ any more than any other property right vested under or recognized by the common law..$^{50}$ On the other hand it is said that no one has a vested right in any principle of the common law and that the court is free to adopt a new rule. ${ }^{51}$ So it is claimed that while Lux v. Haggin is res adjudicata as to the parties therein involved, it is merely a precedent which may be overruled by the Supreme Court and a new principle adopted, as has been done in other phases of water law. ${ }^{52}$ Furthermore it is argued that riparian rights are not abolished but merely defined so as to make certain what has been uncertain heretofore. It is also suggested that the act is merely

of Justices (1909) 103 Me. 506, 69 Atl. 627 (small forest trees); State v. Van Vlack (1918) 101 Wash. $503 ; 172$ Pac. 563 (statute forbidding taking of clams applied to private tide lands).

18 Supra, n. 4.

49 Supra, n. 44.

so 12 C. J. $955,958,960$.

51 Hudson County Water Co. v. McCarter (1908) 209 U. S. 349, 52 L. Ed. 828 , 28 Sup. Ct. Rep. 529; U. S. v. Rio Grande, etc. Co. (1898) 174 U. S. 690; 43 L. Ed. 1136, 1141, 19 Sup. Ct Rep. 770; Gray v. Reclamation Dist. (1917) 174 Cal. 622, 651-2, 163 Pac. 1024, citing cases involving surface waters. Note that Nevada first applied the riparian doctrine but later overruled its earlier decision to apply the doctrine of appropriation. I Wiel, Water Rights (3d ed.) p. 142.

52 Thus in Katz v. Walkinshaw (1904) 141 Cal. 116, 74 Pac. 766, our Supreme Court adopted a "riparian" doctrine of correlative ownership for underground waters though it had to overrule many cases decided upon the principle of absolute appropriative ownership. So it is said that California has adopted the civil law rule of surface waters in lieu of the supposed common law rule. The cases are collected in 8 California Law Review, 197. 
regulatory, ${ }^{53}$ also that it establishes only a rule of evidence as to the extent of the riparian right. 54

\section{Importance of Chotce of Theory}

It is not the purpose of this article to uphold any particular theory but merely to suggest some of the consequences of the adoption of particular theories. Irrespective of whether the Supreme Court upholds the right to store on any theory, storage is inevitable as an economic necessity. If it can not be done by virtue of the exercise of riparian or appropriative rights it will be done by public utilities or irrigation districts by virtue of the right of eminent domain. If the rights of lower riparians have to be compensated, the public will ultimately pay for them in the form of higher electricity and irrigation bills, even though the amount may be inappreciable to any one consumer. If storage can be done without such compensation, it is still an important question as to whether the owners of reservoirs will enjoy the same under the monopoly priority of the apppropriator or the correlative right of the riparian.

If the right be placed upon the appropriative doctrine, every riparian right in the state will be menaced, for such reservoirs are on the upper reaches of our rivers, and every exercise of an appropriate right is per se adverse to the riparians below and initiates the running of the statute of limitations. ${ }^{.5}$ By placing the storage right on an appropriative basis in this way, and holding that the lower riparian cannot object, the court would in effect force the lower riparian to stand idly by until prescription destroyed whatever rights he was not actually putting to use. Conversely the appropriation interests fear that the recognition of the riparian right to store will encourage riparian owners of land on upper parts of rivers, which land, perhaps is now being used for nothing, to construct reservoirs which will interfere with the flow now received by appropriators. By placing the storage right on appropriative principles the court would in effect award a monopoly to the first person storing water on a particular stream, for by the doctrine of appropriation the first comer

53 But see Charnock v. Rose (1886) 70 Cal. 189, 11 Pac. 625, holding invalid an act purporting to create local water boards with powers to control and regulate water courses.

$6 \&$ Lux v. Haggin, 69 Cal. 255, 377, refers to power of legislature to change a rule of evidence as to conflicting water rights.

${ }_{55}$ Pabst v. Finmand, 190 Cal. 124, 132-3; Horst v. Tarr Mining Co., 174 Cal. 430, 436; Miller \& Lux v. Enterprise Co., 169 Cal. 415, 445-6; Heilbron v. Last Chance Water Ditch Co. (1888) 75 Cal. 117, 121-3, 17 Pac. 65. 
gets an absolute right to the extent of his priority and so long as he maintains the same for beneficial use need not share his use with later appropriators, no matter how scarce water may become, ${ }^{58}$ while as among riparians priority gives no better or additional right and the first user must share the water with all other riparians.

If the right be placed upon riparian principles it will always be subject to judicial regulation. It is well settled that as among riparians no one has an absolute right, but only a correlative one, and that any one riparian may apply to the court to apportion and regulate the right to meet changing conditions. ${ }^{57}$ Under these riparian principles it would be proper for a court to let a power company take water at flood times and in the winter, and also to let the irrigator have it during the irrigating season. It could make such regulations as would assure all riparians their share of the water at proper times. To put the right on a riparian basis would exclude those who do not own or purchase riparian land. But the exclusion of nonriparian interests has not heretofore prevented the acquisition of such rights by prescription, purchase, condemnation and otherwise. In the address of Chief Justice Shaw, already cited, he says that

"the irrigated land in the state is almost all non-riparian, and the existence of the riparian right has not prevented the beneficial use of the greater part of the waters of the streams."58

Joseph C. Sharp.

San Francisco, California.

561 Wiel, Water Rights ( $3 \mathrm{~d}$ ed.) p. 311, stating that "in times of natural or other deficiency ... the prior appropriator may still claim his full amount; the loss must fall on the later appropriators." Note that in Iux v. Haggin, $69 \mathrm{Cal}$. 255, 309-310, the court says "it does not require a prophetic vision to anticipate that the adoption of the rule, so called, of 'appropriation' would result in time in a monopoly of all the waters of the state by comparatively few individuals, or combinations of individuals controlling aggregated capita!, who could either apply the water to purposes useful to themselves, or sell it to those from whom they had taken it away, as well as to others."

57 Supra, n. 19.

s8 189 Cal. 779, 793. 